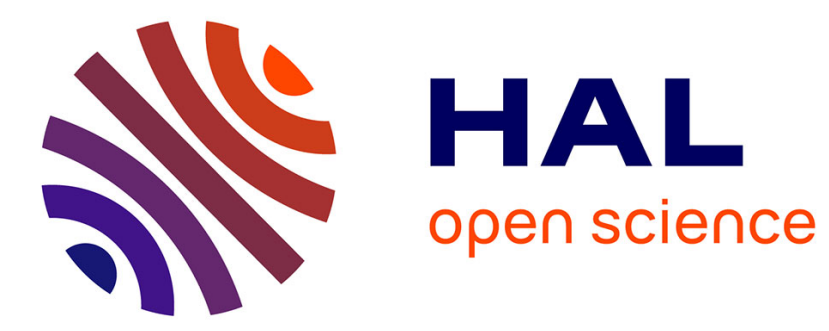

\title{
Distribution of DDT and Other Persistent Organic Contaminants in Canyons and on the Continental Shelf off the Central California Coast
}

S. Ian Hartwell

\section{- To cite this version:}

S. Ian Hartwell. Distribution of DDT and Other Persistent Organic Contaminants in Canyons and on the Continental Shelf off the Central California Coast. Marine Environmental Research, 2008, 65 (3), pp.199. 10.1016/j.marenvres.2007.10.004 . hal-00562995

\section{HAL Id: hal-00562995 \\ https://hal.science/hal-00562995}

Submitted on 4 Feb 2011

HAL is a multi-disciplinary open access archive for the deposit and dissemination of scientific research documents, whether they are published or not. The documents may come from teaching and research institutions in France or abroad, or from public or private research centers.
L'archive ouverte pluridisciplinaire HAL, est destinée au dépôt et à la diffusion de documents scientifiques de niveau recherche, publiés ou non, émanant des établissements d'enseignement et de recherche français ou étrangers, des laboratoires publics ou privés. 


\section{Accepted Manuscript}

Distribution of DDT and Other Persistent Organic Contaminants in Canyons and on the Continental Shelf off the Central California Coast

S. Ian Hartwell

PII:

S0141-1136(07)00129-8

DOI:

10.1016/j.marenvres.2007.10.004

Reference:

MERE 3150

To appear in:

Marine Environmental Research

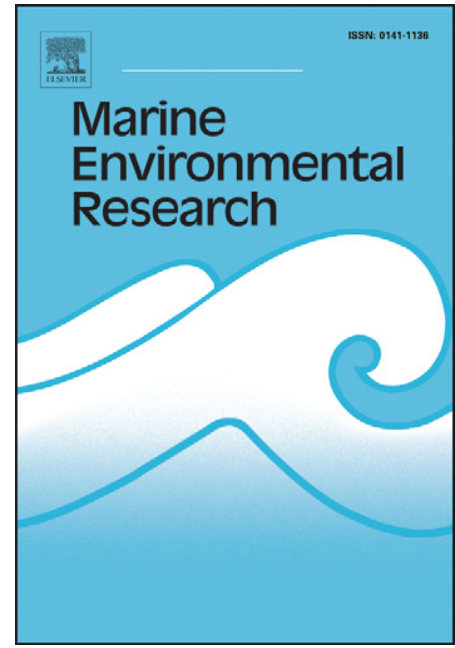

Received Date: $\quad 1$ August 2006

Revised Date: $\quad 9$ October 2007

Accepted Date: $\quad 20$ October 2007

Please cite this article as: Hartwell, S.I., Distribution of DDT and Other Persistent Organic Contaminants in Canyons and on the Continental Shelf off the Central California Coast, Marine Environmental Research(2007), doi: 10.1016/ j.marenvres.2007.10.004

This is a PDF file of an unedited manuscript that has been accepted for publication. As a service to our customers we are providing this early version of the manuscript. The manuscript will undergo copyediting, typesetting, and review of the resulting proof before it is published in its final form. Please note that during the production process errors may be discovered which could affect the content, and all legal disclaimers that apply to the journal pertain. 


\title{
Distribution of DDT and Other Persistent Organic Contaminants in Canyons and on the Continental Shelf off the Central California Coast
}

\author{
S. Ian Hartwell
}

NOAA/NOS/NCCOS

Center for Coastal Monitoring and Assessment

1305 East West Hwy

Silver Spring, MD 20910

P (301) 713-3028

F (301) 713-4388

\section{ian.hartwell@noaa.gov}

\section{ABSTRACT}

Sediment samples were collected to delineate the distribution of contaminants along the central California coast. Sampling included a variety of canyons and shelf/slope areas to evaluate contaminant transport patterns and potential delivery to canyons and the continental slope to a depth of $1,200 \mathrm{~m}$. Sediments were collected and analyzed for organic contaminants using standard techniques of the NOAA National Status and Trends Program (NS\&T). DDT is distributed on the shelf within a zone of fine-grained sediments between Half Moon and Monterey Bays. DDT was found at higher concentrations in Ascension, Año Nuevo, and Monterey/Soquel Canyons than in Pioneer and Carmel Canyons, the Gulf of the Farallones, or the continental slope. The Monterey Bay watershed appears to be the primary source of DDT. In contrast, PAHs and PCBs on the shelf appear to be derived primarily from San Francisco Bay. DDT appears to be delivered to the deep ocean via the canyons more than from cross-shelf sediment transport. Sediment budget estimates for the continental shelf north of Monterey Bay need further refinement and more data to account for the movement of material from Monterey Bay onto the shelf.

Keywords- DDT, Monterey Bay, canyons, continental shelf/slope, sediment pollution, agricultural pollution, organic compounds 


\section{ACCEPTED MANUSCRIPT}

\section{INTRODUCTION}

A large variety of contaminants from industrial, agricultural, urban, and maritime activities are associated with marine sediments, including persistent chlorinated organic chemicals, polycyclic aromatic hydrocarbons (PAHs), and trace metals. Critical habitats and food chains supporting many fish and wildlife species involve the benthic environment. Contaminants in the sediments often pose both ecological and humanhealth risks through degraded habitats, loss of fauna, biomagnification of contaminants in the coastal ecosystem, and human consumption of contaminated fish and wildlife. Characterizing and delineating areas of sediment contamination and toxicity are therefore important goals of coastal resource management at NOAA (NOAA, 2006).

The intent of sampling cruises in 2002 and 2004 was to delineate the distribution and fate of persistent organic contaminants including chlorinated pesticides, (e.g. dichloro diphenyl trichloroethane, DDT), PAHs, and Polychlorinated Biphenyls (PCBs) along the central California coast, assess their potential biological impacts, and to provide data for further development of biological indicators in coastal habitats, including response to natural and anthropogenic factors.

Data from 2002 indicated sediment contaminants were not homogeneously distributed between the canyon heads between San Francisco and Monterey (Hartwell, 2004). Relative to the continental shelf and Pioneer Canyon stations, DDT was found at higher concentrations in Ascension and Monterey Canyons. Monterey Bay still receives DDT from terrestrial runoff (Routh, 1972; Mischke et al., 1985; Rice et al., 1993) and may be the source of DDT found in Ascension Canyon. It is unknown to what extent sediment contaminants are being distributed between the shelf and the canyons, or how contaminant loads moving down the canyons may be impacting benthic communities.

Additional sampling designed to investigate and document contaminant distributions and the soft bottom infaunal community in a systematic approach was initiated in 2004. Only the chemical analyses of samples collected in 2002 and 2004 are reported here. Biological data will be reported separately.

\section{METHODS}


Fifty-six sites were selected for the 2002 cruise to target depositional areas, locations of major outfalls and river discharges, transport routes and sinks of contaminants emanating from San Francisco Bay via the Golden Gate and from the municipal Publicly Owned Treatment Works (POTW) discharge site (Southwest Ocean Outfall - SWOO). Stations were initially laid out in a grid pattern and sites were added based on known source locations, the presence of fine-grained depositional zones, the approaches to the heads of Pioneer Canyon, and in the canyon leads beyond the shelf break. Additional stations were included at a fine-grained site south-west of Half Moon Bay, at the head of Ascension Canyon, and six locations in Monterey Bay. The Monterey Bay stations were located near the mouths of the three major freshwater tributaries to Monterey Bay (San Lorenzo, Pajaro, Salinas), and in depositional zones around the canyon rim.

The 2004 sampling rationale was guided by results from 2002. Sampling was prioritized to include a variety of canyons and shelf/slope areas to allow evaluation of contaminant transport patterns along the continental shelf and potential delivery to canyons. Stations were initially stratified on the basis of depth, and were situated in specific locations that were believed to be depositional environments (as opposed to the canyon axis), based on bathymetry from detailed side-scan sonar maps and inferred sediment texture (NMFS, 2004). In addition, sites were selected to provide contrasts of benthic habitat between canyons, and between canyons and stable slope areas.

Preliminary grid lines were laid out to sample sediment at up to eight locations from mid shelf to the shelf break, and down the canyons/slope to a maximum depth of 1,200 m. Target depths were established to bracket the mid-shelf mud zone $(80,110 \mathrm{~m})$, the shelf break $(150,250 \mathrm{~m})$, the oxygen minimum zone below the shelf break, $(475,700,950 \mathrm{~m})$, and below to $1200 \mathrm{~m}$. Pioneer, Ascension, Año Nuevo, Soquel, Monterey and Carmel Canyons were sampled (Figure 1). Two sampling transects on the continental shelf and slope were placed between Pioneer and Ascension Canyons (slope $1 \& 2$ ). A line between Año Nuevo and Soquel Canyons to the so-called Smooth Ridge area (slope 3), and a line between Pt. Lobos and Pt. Sur were established (slope 4). A fifth series of sites approximately $20 \mathrm{~km}$ southeast of Pt. Sur were sampled to provide a contrast with an area where the continental shelf is typically narrow (slope 5). This was not so much a transect 
as a sequence of presumptively depositional locations at the target depths. A true transect was not possible as the bathymetry in this area is irregular and cut by many small gulleys.

Sampling began off San Francisco in Pioneer Canyon and proceeded south along transects roughly perpendicular to the continental slope incline. A dual Van Veen grab sampler $\left(0.1 \mathrm{~m}^{2} /\right.$ each $)$ was deployed at each station, and a CTD cast. All sampling methods and analytical techniques followed standard National Status and Trends Program (NS\&T) methods (Hartwell et al., 2001; Lauenstein \& Cantillo, 1998; Turgeon et al., 1998). Surface sediment (top 2-3 cm) was removed with Teflon-coated titanium scoops from one sampler, homogenized, and apportioned to pre-cleaned glass containers for chemical and physical testing at laboratories ashore. The entire contents of the other grab was for collection of benthic community samples (not reported here). Chemical samples were frozen $\left(-23{ }^{\circ} \mathrm{C}\right)$ until the end of the cruise. Samples for physical testing were refrigerated. A water quality profile (salinity, temperature, conductivity, oxygen) was measured at the surface and bottom with a CTD at each station.

Sampling gear was initially washed with soap, rinsed with deionized water, rinsed with acetone, followed by an acid wash with $10 \%$ hydrochloric acid and again rinsed with deionized water. At each site, the sampler was rinsed with acetone and deionized water immediately prior to sampling. Only the upper 2-3 cm of the sediment was used in order to assure collection of recently deposited materials. A sediment sample was discarded if the jaws of the grab were open, the sample was partly washed out, or if the sediment sample in the grab was less than $5 \mathrm{~cm}$ deep.

Chemical analyses followed standard NOAA NS\&T program methods (Lauenstein and Cantillo, 1998). A broad suite of chemicals were analyzed at each station, including PAHs, PCBs, and chlorinated pesticides. In addition several physicochemical measurements of sediment quality (e.g. grain size, TOC, etc.) were determined. Organic compounds were extracted using a Soxhlet apparatus. Quantitation of PAHs and their alkylated homologues was performed by gas chromatography mass spectrometry (GC/MS). Chlorinated hydrocarbons were quantitatively determined by capillary gas chromatography with an electron capture detector (GC/ECD). Quality control samples were processed in a manner identical to actual samples and included method blanks, duplicates, and matrix spike/matrix spike duplicate (MS/MSD) samples. 
Certified reference materials were extracted with each batch of samples (NIST SRM 2260). Method detection limits were determined following the procedures outlined in CFR 40, part 136 (1999). Surrogate and internal standards were spiked into every sample and quality control sample. Target analytes are listed in Tables 1 and 2.

Organic contaminant concentrations were plotted by location. TOC normalized concentrations were calculated excluding sites with less than $0.1 \%$ TOC to avoid extreme values from sandy sites. The DDT concentrations were $\log _{10}$ transformed to normalize the data for statistical analyses. Throughout this paper "DDT" is defined as the sum of concentrations of DDT and the degradation products DDD and DDE. Analysis of variance was calculated classifying the transformed DDT data by location (canyons, slope transects, shelf above and below Half Moon Bay) and Duncan's Multiple Range Test was used to group the locations using SAS software. Monterey and Soquel Canyon stations were combined because they are essentially the same system. Carmel Canyon was excluded because there was only one data point.

\section{RESULTS}

Grain size distribution is shown in Figure 2 as \% fine-grained material (silt and clay). Monterey and Soquel Canyons were muddy at all depths. The mid-shelf mud belt is obvious on the shelf north of Monterey Bay. Ascension Canyon also has muddy sediment, but not to the same degree as Monterey and Soquel Canyons. Año Nuevo Canyon has coarser grain size than Ascension Canyon despite their proximity. The head of Año Nuevo does not cut as far into the shelf as does Ascension Canyon, but even at the $80 \mathrm{~m}$ shelf sites, the grain sizes differ. Sediment on the shelf north of Half Moon Bay was generally sandy. Deposits in Pioneer Canyon reflect this trait and contain little finegrained material except at the deepest site. Sorting coefficients are shown in Figure 3. Most locations are poorly or very poorly sorted. Sediment appears to be reworked by currents on the shelf in the Gulf of the Farallones and around the shallow perimeter of Monterey Bay. However there is no apparent pattern in the Gulf of the Farallones, as sites with poorly sorted sediments are intermixed with more well sorted locations. Virtually all of the deeper sites were poorly sorted, whether in canyons or on the slope. The total organic carbon (TOC) content of the sediments ranged from $0.03 \%$ to a maximum of 
$2.3 \%$ with a median of $0.51 \%$. Consistent with the grain size pattern, sediments in the Gulf of the Farallones had low organic carbon values relative to the other sampling areas (Figure 4). The slope sediments exhibited increasing TOC content with depth.

Data from the 2004 cruise confirmed the presence of elevated DDT in Ascension and Año Nuevo canyons relative to sites in the Gulf of the Farallones to the north. In addition, elevated DDT concentrations were documented to a depth of at least 1,200 m (Figure 5). The highest concentration $(16.7 \mathrm{ug} / \mathrm{kg}$ ) was at the head of Monterey Canyon. The presence of DDT at nearly equal concentrations on the shelf and in Ascension and Año Nuevo Canyons indicates transport of fine-grained materials out of the Monterey Bay system to the shelf to the north, and down the canyons. Contaminants do not appear to be accumulating on the slope in the Smooth Ridge area between Monterey Bay and Pt. Año Nuevo. Contaminant concentrations in Carmel canyon and on the shelf south of Monterey Bay did not appear to be elevated above background levels. However, due to weather conditions, only the head of Carmel Canyon was sampled. The DDT concentrations were slightly elevated at two stations on the slope south of Pt. Sur. The other pesticides that were analyzed were found at very low concentrations, generally at or below detection limits at about half the stations, and further data analysis would be an over-interpretation.

Analysis of variance of $\log _{10}$ transformed DDT concentration (dry weight) showed significant differences between locations $(\mathrm{F}=26.5,10 \mathrm{df}, \mathrm{P}>\mathrm{F}<0.0001)$. Duncan's Multiple Range test separated the stations into four groups (Table 3) with some overlap. The Monterey Bay stations were in a single group. Ascension Canyon, shelf sites below Half Moon Bay, and the Slope 5 transect were in the second group. The last two overlapping groups were made up of Pioneer and Año Nuevo Canyons, the remaining slope transects and the northern shelf stations. Excluding the shallow shelf stations from the Slope 4 and 5 transects (to be consistent with the division by depth in the other shelf groups) did not alter the results. Even though the slope 3 transect lies between Monterey Bay and Ascension/Año Nuevo canyons, DDT concentrations on the slope below the shelf break are not elevated. This indicates little cross shelf sediment transport without a canyon head cutting into the shelf. 


\section{ACCEPTED MANUSCRIPT}

Sediments with higher concentrations of TOC will accumulate higher concentrations of non-polar organic contaminants than sediment with low TOC receiving similar loadings of contaminants. Concentrations of DDT normalized for TOC content shows where concentrations are elevated after adjusting for the affinity of the sediment for organic compounds (Figure 6). In this case sediments with less than $0.1 \%$ TOC were eliminated (6 stations) because very small values lead to spurious calculations. These were all coarse, sandy sediment locations. The distribution of high concentration stations clearly implicates Monterey Bay as the source of the DDT in the region. Similar to DDT, the absolute concentrations of PAHs and PCBs show higher accumulations in Monterey Bay and Ascension Canyon than most (but not all) stations in the Gulf of the Farallones. Organic contaminants do not appear to accumulate in the sandy sediments in Gulf of the Farallones at the mouth of the Golden Gate. None of the observed concentrations exceed the respective ERLs values (Long et al., 1995). The maximum concentrations were 614 and $2.6 \mathrm{ppb}$ for PAHs and PCBs respectively. However, plots of TOC normalized PAHs and PCBs yield a different pattern than for DDT. Normalized values point to San Francisco Bay (Figures $7 \&$ 8) and the Southwest Ocean Outfall (SWOO) sewage discharge as the main source of these contaminants in the Gulf of the Farallones. Concentrations of PAHs and PCBs within San Francisco Bay are very high in several locations, ranging from 30 to over 20,000 ppb PAHs in selected harbors ( median value $=$ 2,338), and from less than 1 to over $350 \mathrm{ppb}$ PCBs (median value $=11 \mathrm{ppb})$. DDT concentrations in San Francisco Bay are also high at selected stations in the Bay (Hartwell, 2004). However, the export of most of the DDT on the shelf appears to be derived from the Monterey Bay watershed rather than San Francisco Bay.

\section{DISCUSSION}

Forecasting persistent contaminant concentrations within the estuary and contaminant export to the coastal ocean is a major issue within the San Francisco Bay research community (Phillips, 1987; Risebrough, 1997; Davis et al., 2000; Davis, 2004; Leatherbarrow et al., 2005; Davis et al., in press) and has serious ramifications with respect to existing and proposed dredging operations within the system. Sediment budgets within the Bay suggest that it is becoming a net sediment exporting system due 
to anthropogenic changes in sediment delivery processes within the watershed (Geen \& Luoma, 1999; Jafee et al., 1998; McKee et al., 2006).

There are other factors that may impact contaminant delivery to the continental shelf in this vicinity. There are three smaller POTW (Publicly Owned Treatment Works) sewage outfalls off San Francisco and Half Moon Bay. Two are located in relatively shallow water $(\sim 10 \mathrm{~m})$ and one currently discharges into an artificial wetland on shore. However, these are relatively small (2.3, 3.7 , and 7.5 mgd, 2006 data) (RWQCB, 2007) releases of secondary and tertiary treated domestic sewage without industrial input. In contrast, the SWOO discharge varies between 18-175 mgd (depending on season) of treated domestic sewage, industrial effluents and stormwater runoff (SFPUC, 2003).

There are two active dredge spoil disposal sites in the region. One is used for sidecasting of sand from the main ship channel leading into San Francisco Bay onto the ebb tidal shoal adjacent to it. This is reportedly clean sand that shoals in the channel, and is placed immediately to the south of the channel so as to keep it in the same overall littoral transport system. Fairly large volumes are moved in this way each year $(500,000$ 750,000 cy) (EPA, 2007). Since it is moved from one place on the shelf to an adjacent place, there is no net transfer of contaminants to the shelf system. The second site (the San Francisco Deep Ocean Disposal Site, SF-DODS) is approximately $92 \mathrm{~km}$ offshore in at a depth of 3,000 m, in a trough at the base of the continental slope. Several million cubic yards of material from harbor areas in San Francisco Bay have been disposed of there. Dredge spoil from US Navy facilities and military munitions were dumped in the vicinity of this site prior to 1972 , when the practice was banned. While it is deeper and further offshore than the current study area, upwelling currents and lateral transport of fine-grained material is possible during disposal. However, material that is currently dumped there must pass screening toxicity and chemical analysis testing.

Residues of DDT and it's metabolites enter Monterey Bay primarily from stromwater runoff from agricultural land (Routh, 1972; Mischke et al., 1985; Rice et al., 1993; CCLEAN, 2005). Although DDT is no longer used on crops, there is a large residual mass stored in sediments within the watersheds. Measured loads of DDT and other persistent organic contaminants from the rivers in the wet season are an order of magnitude greater than during the dry season. There are three shallow offshore POTW 
discharges into Monterey Bay and one in Carmel Bay. As with the smaller POTWs in the Gulf of the Farallones, these receive input primarily from domestic sanitary sewers. Annual loadings from the watersheds are several times greater than the loadings seen from sewer discharges (CCLEAN, 2005) for all organic constituents. Flow from the Monterey Regional plant varies between 3-15 mgd depending on season. The Santa Cruz and Watsonville Regional plants discharge approximately $10 \mathrm{mgd}$ or less, regardless of season. The discharge from the Carmel Bay plant discharge is generally below $1 \mathrm{mgd}$. Moss Landing Harbor sediment contains elevated levels of DDT derived from the watershed. That harbor is dredged periodically, and some of the material is dumped at the head $(\sim 150 \mathrm{~m})$ of Monterey Canyon as a slurry. The volume of permitted spoil material may be as much as 76,000 m3, but this is an upper permit limit. Estimates of sediment input from the Salinas R. alone are nearly 2,000,000 m3 (Eittreim et al., 2002).

DDT has a low water solubility and transport is primarily associated with finegrained sediment. The Salinas River is estimated to contribute more than 5 and $8 \mathrm{X}$ the fine-grained sediment load to Monterey Bay than the Pajaro and San Lorenzo Rivers, respectively, although the bulk of DDTs appears to come from both the Pajaro and Salinas Rivers (CCLEAN, 2005). The fate of fined-grained sediment in Monterey Bay is not accurately known. Water currents in this area are complex, and are influenced by the geology of the region. Offshore, surface flow is dominated by the southward flowing California current. Upwelling is common during the spring/summer months, bringing deep ocean water onto the shelf. Upwelling currents are most prominent near Pt. Reyes, Pt. Año Nuevo, and Pt. Sur. While upwelling up the Monterey Canyon axis to the surface has not been documented (Rosenfeld et al., 1994), strong tidal currents oscillate in the canyon with a net up-canyon transport of deep water (Broenkow \& Smethie, 1978). The California undercurrent flows north beneath the surface current. During the winter months the surface flow reverses to the north in a phase referred to as the Davidson Current.

Within Monterey Bay, circulation is cyclonic 2/3 of the year with periodic reversals in early spring and fall (Breaker \& Broenkow 1994). The net flow delivers water and sediments to the northern rim of the Bay which may be transported north or south on the continental shelf, depending on the prevailing coastal current direction and 
depth. During calm summer months, fine-grained sediments derived from the previous winter's watershed and shoreline erosion deposit on the shelf north and south of the canyon along with settling plant material, resulting in highly organically enriched conditions. DDT accumulates in these deposits. These sediments are transported by bottom currents to either Monterey Canyon or out of Monterey Bay onto the mid-shelf mud belt north of Monterey Bay. The rim of the canyon accumulates large volumes of fine-grained sediment. With the onset of seasonal storm-driven wave action, these materials may be disrupted and move down the canyon. The frequency of these events is unknown. Large sediment turbidity flow events have been observed at all depths in the canyon, and may last for a week or more, resulting in large suspended sediment volumes moving down the canyon (Martini, 2004; Xu et al., 2002a). Paull et al., (2002) concluded that DDT laden sediment delivered to Monterey Canyon was diluted with clean sediment from other sources and transported down the canyon during the annual winter storm season. They also concluded that little DDT is deposited on the flanks of the canyon, and virtually none is deposited in the inter canyon areas on the continental shelf south of Monterey Bay.

A preliminary sediment budget for the Monterey Bay and the adjacent Santa Cruz shelf was generated by Eittreim et al. (2002).Their calculations indicate a fine-grain sediment deficit on the mid-shelf mud belt north of Monterey Bay, unless a significant portion of the material from the Salinas River watershed is transported across Monterey Canyon to the northern bay for export to the continental shelf. However, Eittreim et al. (2002) concluded that offshore shelf by-passing is the dominant sink of fine-grained sediment from the shelf south of Monterey Canyon based on ${ }^{210} \mathrm{~Pb}$ accumulation rates. They further conclude that significant sediment by-passing from south to north is not a major transport pathway over the canyon because it is too wide for sediment plumes to cross.

Imagery from Sea-viewing Wide Field-of-View Sensor (SeaWiFS) satellite ocean color data can be used to track sediment plumes. Turbidity can be inferred from sea surface reflectance at a wavelength of $670 \mathrm{~nm}$, which indicates red light reflected from the water. At $670 \mathrm{~nm}$, chlorophyll pigment absorption is weak, and reflectance indicates scattering due to sediments (Stumpf et al., 2005). The pattern varies over time, but the 
images clearly show that sediment plumes are crossing Monterey Canyon from south to north during the wet season, when DDT laden sediment is being flushed from the watersheds. Figure 9 shows the SeaWiFS image from Feb. 9, 1998, two days after a particularly large rain storm. Mertes and Warrick (2001) estimated the sediment load in the plume from the Salinas River alone to be 83,030 tons during this single event.

So, where does the sediment accumulating on the mid-shelf mud belt primarily come from? In the mid-shelf mud belt, fine-grained sediments move north from Monterey Bay (Eittreim et al., 2002; Xu et al., 2002a). As noted above, current data indicates that there is an inadequate volume of fine-grained material emanating from the northern Monterey Bay to account for the mass of material moving over the mid-shelf mud belt. The source estimates need refinement, as sediments are by-passing the canyon from the southern portion of Monterey Bay based on satellite imagery. It has been suggested that deposits in the ebb tidal shoals off the Golden Gate may be an unaccounted source of contaminated sediment to the mid-shelf mud belt to the south (Eittreim et al., 2002). However, contaminants do not appear to accumulate in the Gulf of the Farallones sediments at the mouth of the Golden Gate. They also note that if sediment loss down canyons is significant, the deficits would be even greater than calculated. The data clearly show that sediment transport down both canyons in Monterey Bay and up the coast in Ascension and Año Nuevo canyons is a significant sink based upon the DDT concentrations. Xu et al. (2002b) demonstrated that oscillating tidal currents within Monterey Canyon are sufficient to resuspend fine-grained bottom sediments on a regular basis, if not continuously at depths below $1000 \mathrm{~m}$. A nephaloid layer was persistent at the bottom. The water currents at the rim of the canyon showed a distinct disconnect between the surface water and water in the canyon. Eittreim et al., (2002) also noted a "pervasive" bottom nephaloid layer up on the shelf. Data is needed to determine what suspended sediment dynamics are present in the shallower portions of Monterey Canyon, where the width of the canyon does not preclude transport of large volumes of suspended sediments from the southern to northern shelf, and where sediments may be entrained from up-canyon tidal currents into surface layer currents to be carried away to the north. Two moorings with bottom and mid-depth current meters, turbidity meters, and sediment 
traps were place at the heads of Monterey and Soquel Canyons in 2005 to address these issues. They were retrieved in 2006 and data is currently being analyzed.

Submarine canyons are prominent conduits of sediment/contaminant transport to deeper waters. Does all the DDT go down the submarine canyons first and then redistribute to slopes, or is there another down-slope transport mechanism? Can this down canyon transport account for most of the DDT found both in the canyons and on the slope? Little is known about current regimes or sediment dynamics in Soquel Canyon. The sources and relative magnitude of DDT and other persistent pesticides must be determined if appropriate runoff control efforts are to be used in targeted watersheds to control stormwater runoff and release to the Monterey Bay National Marine Sanctuary (MBNMS). If sediment source terms in the sediment budgets are correct, alternative sources of contaminants will need to be investigated. Conversely, if the sediment source terms in the sediment budgets are not correct, the relative magnitude of contaminant inputs to MBNMS from differing watersheds must be addressed. The transport and fate of sediment-borne contaminants in Monterey Bay and it's canyon system are of central importance to assessing the fate and effects of anthropogenic contaminants in the MBNMS.

Tissue concentrations in mussels sampled by both the NS\&T Mussel Watch and the CCLEAN Programs (http://NSandT.noaa.gov; CCLEAN, 2005) exceed local screening values and guidelines indicating that contamination of nearshore shellfish in the Monterey Bay area may be of concern for both human and wildlife health, such as sea otters, that consume mussels and other bivalves. It is unknown to what extent sediment loads moving down the canyons may be impacting the deep communities. DDT concentrations in Monterey Bay biota indicate bioaccumulation is occurring at depth. Little is known about the biota of deep water, soft bottom benthic habitats on the outer continental shelf or continental slope in this region (MBNMS, 1996). Some systematic benthic community data sets do exist, including the samples collected by NOAA which are currently being assessed. Patterns of DDT body burdens observed in fish with different depth and feeding habits may reflect food chain transfer from the benthic community. Shaw (1972) and Looser et al. (2000) found that benthic feeding fish had higher body burdens of DDT and metabolites than did pelagic fish. Looser et al. (2000) 
further observed that deep dwelling species had higher body burdens than shallow species. Body burdens in fish from the Monterey Bay area were higher than comparable deep and surface water species from the Atlantic Ocean. The benthic brittle star Amphiura archystata had higher body burdens than any of the fish species $(3,340 \mathrm{ug} / \mathrm{kg}$ lipid). Eganhouse et al. (2000), and Zeng \& Tran (2002) conclude that DDT is constantly being remobilized from sediments to the water column and the benthic food chain, resulting in contamination of locations away from discharge sources at Palos Verdes, Calif. It is reasonable to assume the same processes are operating in the central California shelf and slope environments.

\section{ACKNOWLEDGMENTS}

I wish to acknowledge the efforts of the crew of NOAA ship McArthur II and the members of the science party from NOAA, USGS, and Moss Landing Marine Laboratory for much hard work under sometimes difficult conditions. Superior training and preparation by the ship's officers and crew, and the US Coast Guard Monterey Medevac team enabled them to manage a life threatening medical emergency with complete success. Sampling was conducted under National Marine Sanctuaries Permit MBNMS2004-012.

\section{REFERENCES}

Breaker, L.C. \& Broenkow W.W. (1994). The circulation of Monterey Bay and related processes. Oceanography and Marine Biology: an Annual Review, 32,1-64.

Broenkow, W.W. \& Smethie, W.M. (1978). Surface circulation and replacement of water in Monterey Bay. Estuarine and Coastal Marine Science, 6, 583-603.

CCLEAN, (2005). Central coast long-term environmental assessment network, 20032004 annual report. CCLEAN, Santa Cruz, CA.

CFR (Code of Federal Regulations) 40. 1999. Guidelines for Establishing Test procedures for the Analysis of Pollutants Under the Clean Water Act. CFR 40, part 136, appendix A: 114-328.

Davis, J.A., McKee, L., Leatherbarrow, J \& Daum, T. (2000). Contaminant loads from stormwater to coastal waters in the San Francisco Bay region: Comparison to other pathways and recommended approach for future evaluation. San Francisco Estuary Institute, Richmond, CA. 
Davis, J.A. (2004). The long term fate of PCBs in San Francisco Bay. Environmental Toxicology and Chemistry, 23, 2396-2409.

Davis, J.A., Hetzel, F.\& Oram, J.J. (In press). Polychlorinated biphenyls (PCBs) in San Francisco Bay. Environmental Research.

Eganhouse, R.P., Pontolillo,J. \& Leiker, T.J. (2000). Diagenetic fate of organic contaminants of the Palos Verdes shelf, California. Marine Chemistry, 70, 289-315.

Eittreim, S.L., Xu, J.P., Nobel, M.\& Edwards, B.D. (2002). Towards a sediment budget for the Santa Cruz shelf. Marine Geology, 181, 235-248.

EPA. 2007. Region 9, Dredging \& Sediment Management Team, San Francisco, CA

Geen, A \& Luoma, S.N. 1999. The impact of human activities on sediments of San Francisco Bay, California: an overview. Marine Chemistry 64, 1-6.

Hartwell, S.I., Hameedi, M.J. \& Harmon, M. (2001). Magnitude and extent of contaminated sediment and toxicity in Delaware Bay. NOAA Tech. Memo.

NOS/NCCOS/CCMA 148. National Oceanic and Atmospheric Administration, National Ocean Service, Silver Spring, Maryland

Hartwell, S.I. (2004). Distribution of DDT in sediments off the central California coast. Marine Pollution Bulletin, 49, 299-305.

Jaffe, B.E., Smith, R.E., \& Torresan, L.Z. 1998. Sedimentation and bathymetric change in San Pablo Bay: 1856-1983. U.S. Geological Survey Open-File Report 98-759

Lauenstein, G.G. \& Cantillo, A.Y. (eds.). (1998). Sampling and analytical methods of the national status and trends program mussel watch project: 1993-1996 update. NOAA Tech. Memo. NOS ORCA 130. NOAA, Silver Spring, Maryland.

Leatherbarrow, J.E., McKee, L.J., Schoellhamer, D.H., Ganju, N.K. \& Flegal, A. R. (2005). Concentrations and loads of organic contaminants and mercury associated with suspended sediment discharged to San Francisco Bay from the Sacramento-San Joaquin river delta, California RMP technical report. SFEI Contribution 405. San Francisco Estuary Institute. Oakland, California.

Long E.R., MacDonald, D.D., Smith, S.L. \&Calder, F.D.(1995). Incidence of adverse biological effects within ranges of chemical concentrations in marine and estuarine sediments. Environmental Management, 19,81-97.

Looser, R., Froescheis, O., Cailliet, G.M., Jarman, W.M. \& Ballschmiter, K. (2000). The deep-sea as a final global sink of semivolatile persistent organic pollutants? Part II: 
Organochlorine pesticides in surface and deep-sea dwelling fish of North and South Atlantic and the Monterey Bay Canyon (California). Chemosphere, 40, 661-670.

MBNMS. (1996). Monterey Bay National Marine Sanctuary Site Characterization. National Oceanographic \& Atmospheric Administration, NOS, MNS, MBNMS, Monterey, California, 1996.

McKee L.J., Neil, K. Ganju, N.K., \& Schoellhamer, D. H. 2006. Estimates of suspended sediment entering San Francisco Bay from the Sacramento and San Joaquin Delta, San Francisco Bay, California. Journal of Hydrology 323 (2006) 335-352.

Mertes, L.A.K., and J.A. Warrick, 2001. Measuring Flood Output from 110 Coastal Watersheds in California with Field Measurements and SeaWiFS. Geology. V. 29 7:659662.

Mischke, T., Brunetti, K., Acosta, V., Weaver, D. \& Brown, M. (1985). Agricultural sources of DDT residues in California's environment. Environmental Hazards Assessment Program California Dept. of Food and Agriculture, Sacramento, California.

NMFS. (2004). Pacific coast groundfish essential fish habitat project consolidated GIS data, Vol. 1: Physical and biological habitat. NOAA, National Marine Fisheries Service, Silver Spring, Maryland.

NOAA (2006). http://oceanservice.noaa.gov/topics/coasts/contaminants

Paull, C.K., Greene, H.G., Ussler, W. \& Mitts, P.J. (2002). Pestcides as tracers of sediment transport through Monterey Canyon. Geo-Marine Letters, 22, 121-126.

Phillips, D.J.H.(1987). Toxic contaminants in the San Francisco Bay-Delta and their possible biological effects. San Francisco Estuary Institute, Oakland, CA.

Rice, D.W., Seltenrich, C.P., Spies, R.B. \& Keller, M.L. (1993). Seasonal and annual disrtibution of organic contaminants in marine sediments from Elkhorn Slough, Moss Landing harbor and nearsheore Monterey Bay, California. Environmental Pollution, 82, 79-91.

Risebrough, R.W. (1997). Polychlorinated biphenyls in the San Francisco Bay ecosystem: A preliminary report on changes over three decades. In, Regional Monitoring Program for Trace Substances-1995 Annual Report (pp. 287-297). San Francisco Estuary Institute, Oakland, CA.

Rosenfeld, L.K., Schwing, F.B., Garfield, N. \&.Tracy, D.E. (1994). Bifurcated flow from an upwelling center: a cold water source for Monterey Bay. Continental Shelf Research, $14,931-964$. 


\section{ACCEPTED MANUSCRIPT}

Routh, J.D.(1972). DDT residues in Salinas River sediments. Bulletin of Environmental Contamination and Toxicology, 7, 168-176.

RWQCB (Regional Water Quality Control Board). 2007. DMR data reports. Calif. Environ. Protection Agency, Regional Water Quality Control Bd., Oakland, CA.

SFPUC9 San Francisco Public Utilities Commission. 2003. Southwest Ocean Outfall Regional Monitoring Prog., Five-Year Summary Rept. 1997-2001. San Fran. Pub. Util. Comm., Water Qual. Bur., San Francisco, CA. 216pp.

Shaw S.B. 1972. DDT residues in eight California marine fishes. Calif. Fish \& Game, $58: 22-26$.

Stumpf, R, S. Dunham, L. Ojanen, A. Richardson, T. Wynne, and K. Holderied, 2005. Characterization and Monitoring of Temperature, Chlorophyll, and Light Availability Patterns in National Marine Sanctuary Waters: Final Report. NOAA Technical Memorandum NOS NCCOS 13. NOAA/NOS/NCCOS/CCMA, Silver Spring, MD. $48 \mathrm{pp}$.

Turgeon, D.D., J. Hameedi, M.R. Harmon, E.R. Long, K.D. McMahon, and H.H. White. 1998. Sediment Toxicity in U.S. Coastal Waters. NOAA, National Ocean Service, National Status and Trends Program. Silver Spring, MD. 20 pp.

Xu, J.P., Noble, M., \& Eittreim, S.L. (2002)a. Suspended sediment transport on the continental shelf near Davenport, California. Marine Geology, 181, 171-193.

Xu, J.P., Noble, M., Eittreim, S.L., Rosenfeld, L.K., Schwing, F.B. \& Pilskaln, C.H. (2002)b. Distribution and transport of suspended particulate matter in Monterey Canyon, California. Marine Geology, 181, 215-234.

Zeng, E.Y. \& Tran, K. (2002). Distribution of chlorinated hydrocarbons in overlying water, sediment, polychaete, and hornyhead turbot (Pleuronichthys verticalis) in the coastal ocean, southern California, USA. Environmental Toxicology and Chemistry, 21, 1600-1608. 
Table 1. Polynuclear aromatic hydrocarbons analyzed in sediment samples, and minimum detection limits (MDL, ppb).

\begin{tabular}{|c|c|c|c|}
\hline Analyte & MDL & C2-Fluoranthenes/Pyrenes & 0.39 \\
\hline Naphthalene & 0.17 & C3-Fluoranthenes/Pyrenes & 0.39 \\
\hline C1-Naphthalenes & 0.33 & Benz(a)anthracene & 0.13 \\
\hline C2-Naphthalenes & 0.35 & Chrysene & 0.17 \\
\hline C3-Naphthalenes & 0.35 & C1-Chrysenes & 0.35 \\
\hline C4-Naphthalenes & 0.35 & C2-Chrysenes & 0.35 \\
\hline Biphenyl & 0.14 & C3-Chrysenes & 0.35 \\
\hline Acenaphthylene & 0.19 & C4-Chrysenes & 0.35 \\
\hline Acenaphthene & 0.13 & Benzo(b)fluoranthene & 0.29 \\
\hline Fluorene & 0.19 & Benzo(k)fluoranthene & 0.23 \\
\hline C1-Fluorenes & 0.39 & Benzo(e)pyrene & 0.31 \\
\hline C2-Fluorenes & 0.39 & Benzo(a)pyrene & 0.22 \\
\hline C3-Fluorenes & 0.39 & Perylene & 1.38 \\
\hline Anthracene & 0.19 & Indeno(1,2,3-c,d)pyrene & 0.28 \\
\hline Phenanthrene & 0.14 & Dibenzo(a,h)anthracene & 0.15 \\
\hline C1-Phenanthrenes/Anthracenes & 0.29 & Benzo(g,h,i)perylene & 0.14 \\
\hline C2-Phenanthrenes/Anthracenes & 0.29 & 18a-Oleanane & 1.11 \\
\hline C3-Phenanthrenes/Anthracenes & 0.29 & Naphthobenzothiophene & 0.20 \\
\hline C4-Phenanthrenes/Anthracenes & 0.29 & C1-Naphthobenzothiophenes & 0.41 \\
\hline Dibenzothiophene & 0.15 & C2-Naphthobenzothiophenes & 0.41 \\
\hline C1-Dibenzothiophenes & 0.31 & C3-Naphthobenzothiophenes & 0.41 \\
\hline C2-Dibenzothiophenes & 0.31 & C29-Hopane & 1.11 \\
\hline C3-Dibenzothiophenes & 0.31 & C30-Hopane & 1.11 \\
\hline Benzothiophene & 0.17 & & \\
\hline C1-Benzothiophenes & 0.35 & 2-Methylnaphthalene & 0.20 \\
\hline C2-Benzothiophenes & 0.35 & 1-Methylnaphthalene & 0.13 \\
\hline C3-Benzothiophenes & 0.35 & 2,6-Dimethylnaphthalene & 0.20 \\
\hline Carbazole & 0.33 & 1,6,7-Trimethylnaphthalene & 0.10 \\
\hline Dibenzofuran & 0.20 & 1-Methylphenanthrene & 0.20 \\
\hline
\end{tabular}

Analyte

Fluoranthene

Pyrene

C1-Fluoranthenes/Pyrenes
MDL

0.21

0.19

0.39 
Table 2. Chlorinated pesticides and PCBs analyzed in sediment samples and minimum detection limits (MDL, ppb).

\begin{tabular}{|c|c|c|c|}
\hline Analyte & MDL & PCB52 & 0.05 \\
\hline Aldrin & 0.10 & PCB66 & 0.04 \\
\hline Dieldrin & 0.07 & PCB101/90 & 0.04 \\
\hline Endrin & 0.12 & PCB 103 & 0.19 \\
\hline Heptachlor & 0.09 & PCB105 & 0.10 \\
\hline Heptachlor-Epoxide & 0.18 & PCB118 & 0.06 \\
\hline Oxychlordane & 0.05 & PCB128 & 0.11 \\
\hline Alpha-Chlordane & 0.04 & PCB138 & 0.06 \\
\hline Gamma-Chlordane & 0.05 & PCB153/132/ & 0.06 \\
\hline Trans-Nonachlor & 0.04 & PCB $170 / 190$ & 0.06 \\
\hline Cis-Nonachlor & 0.07 & PCB180 & 0.06 \\
\hline & & PCB187 & 0.04 \\
\hline Alpha-HCH & 0.09 & PCB195/208 & 0.04 \\
\hline Beta-HCH & 0.07 & PCB 198 & 0.19 \\
\hline Delta-HCH & 0.08 & PCB206 & 0.04 \\
\hline Gamma-HCH & 0.05 & PCB209 & 0.07 \\
\hline 2,4'-DDD & 0.07 & & \\
\hline 4,4'-DDD & 0.11 & & \\
\hline 2,4'-DDE & 0.05 & & \\
\hline 4,4'-DDE & 0.04 & & \\
\hline 2,4'-DDT & 0.10 & & \\
\hline 4,4'-DDT & 0.08 & & \\
\hline Endosulfan II & 0.10 & & \\
\hline Endosulfan I & 0.10 & & \\
\hline Endosulfan Sulfate & 0.11 & & \\
\hline Mirex & 0.04 & & \\
\hline Chlorpyrifos & 0.10 & & \\
\hline Analyte & MDL & & \\
\hline $\mathrm{PCB} 8 / 5$ & 0.10 & & \\
\hline PCB18 & 0.06 & & \\
\hline PCB28 & 0.05 & & \\
\hline PCB44 & 0.10 & & \\
\hline
\end{tabular}


Table 3. Results of Duncan's Multiple Range Test $(\alpha=0.05)$ for $\log _{10}$ transformed DDT concentration data for canyons, slope transects and shelf stations off central California.

\begin{tabular}{|c|l|c|}
\hline $\begin{array}{l}\text { Duncan } \\
\text { Grouping }\end{array}$ & Location & $\begin{array}{l}\text { Concentration range } \\
\text { (ng/gm dry wt.) }\end{array}$ \\
\hline A & Monterey Canyon & $12.1-16.7$ \\
\hline B & Ascension Canyon & $4.6-11.1$ \\
\hline B & Shelf below Half Moon Bay & $2.3-14.8$ \\
\hline B & Slope 5 & $3.3-6.6$ \\
\hline C & Año Nuevo Canyon & $0.6-6.3$ \\
\hline C & Pioneer Canyon & $1.1-7.9$ \\
\hline C D & Slope 2 & $1.1-3.5$ \\
\hline C D & Slope 1 & $1.6-2.8$ \\
\hline C D & Slope 3 & $1.5-3.4$ \\
\hline C D & Slope 4 & $0.8-3.8$ \\
\hline & Shelf above Half Moon Bay & $0.2-2.8$ \\
\hline
\end{tabular}




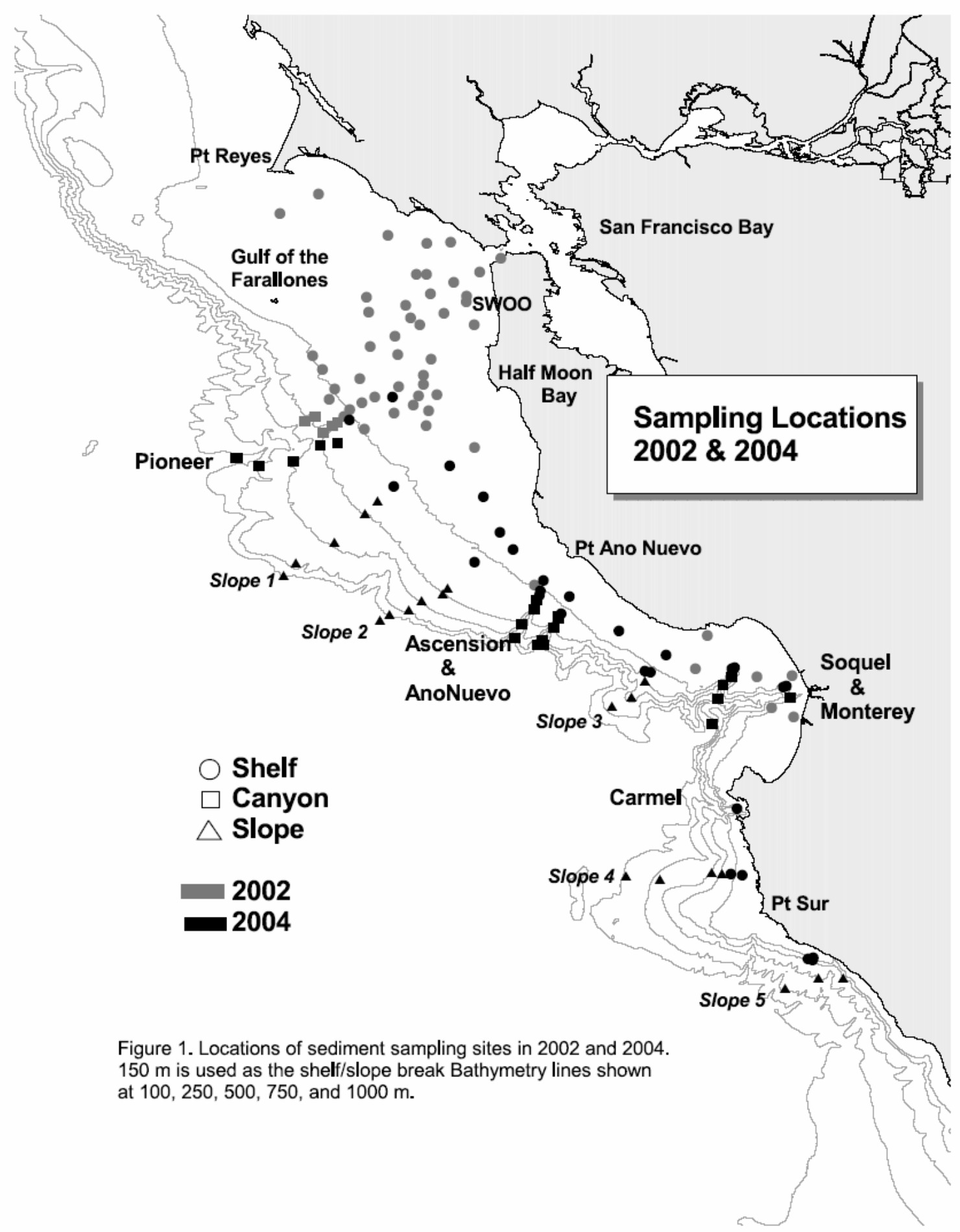




\section{ACCEPTED MANUSCRIPT}

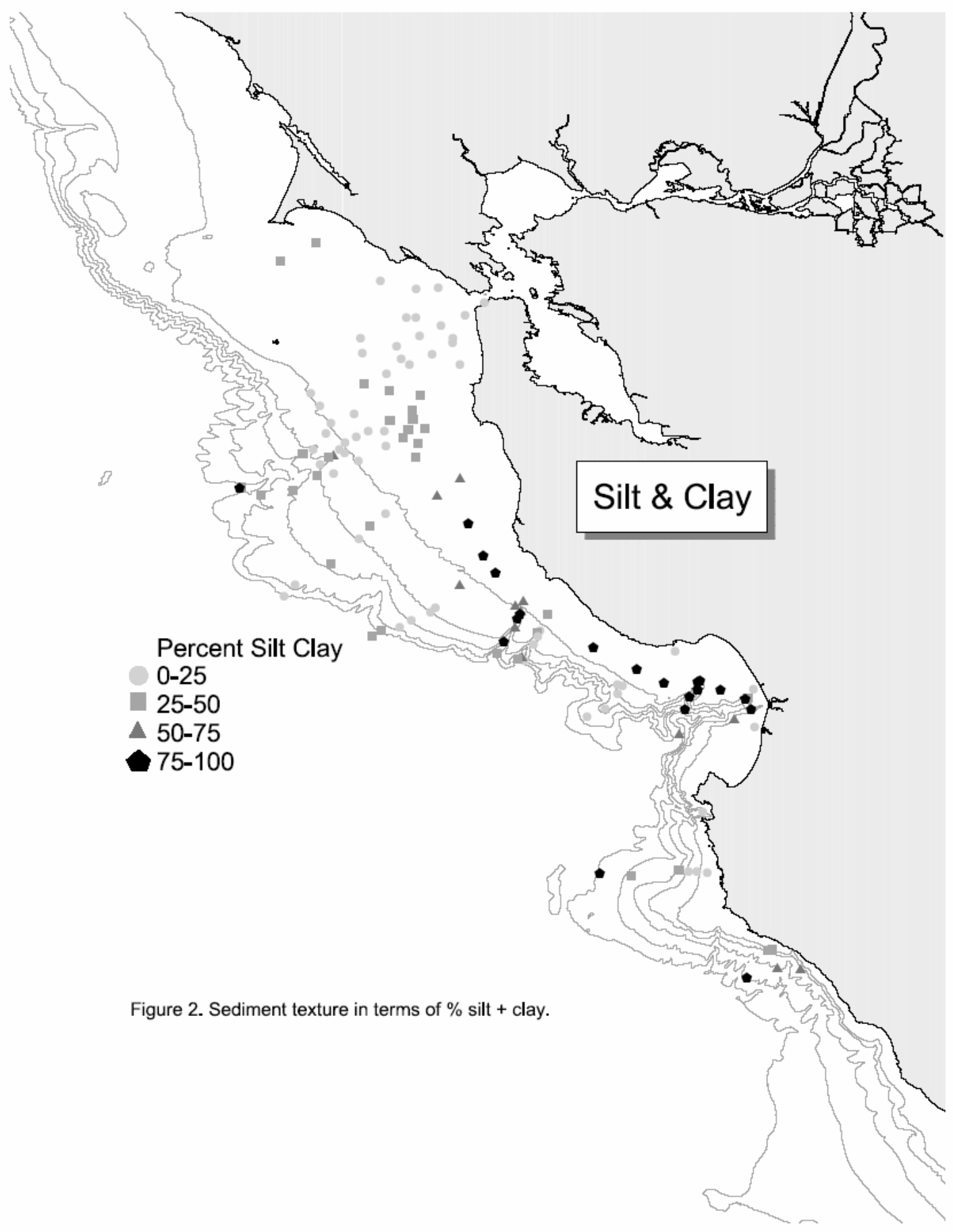




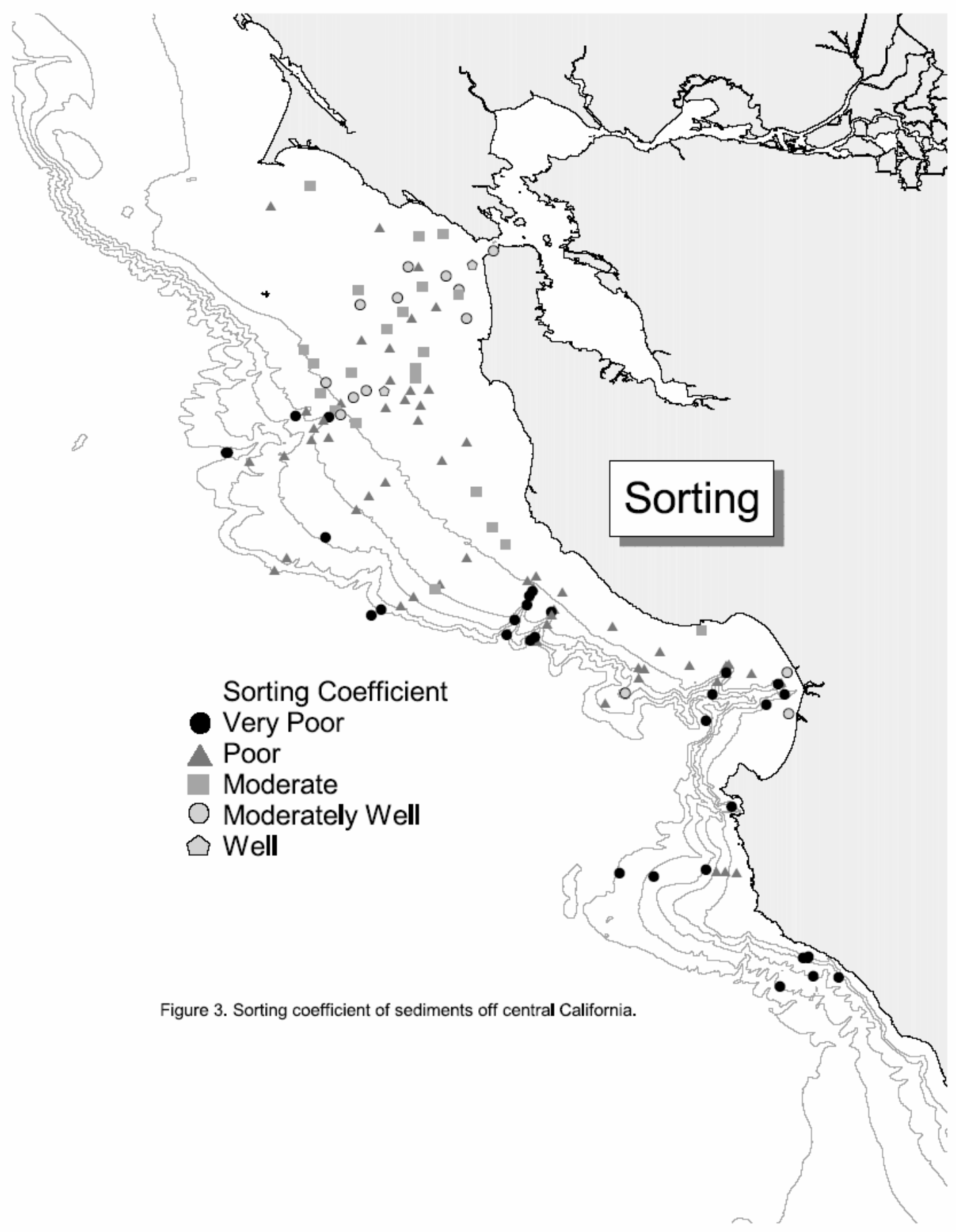




\section{ACCEPTED MANUSCRIPT}

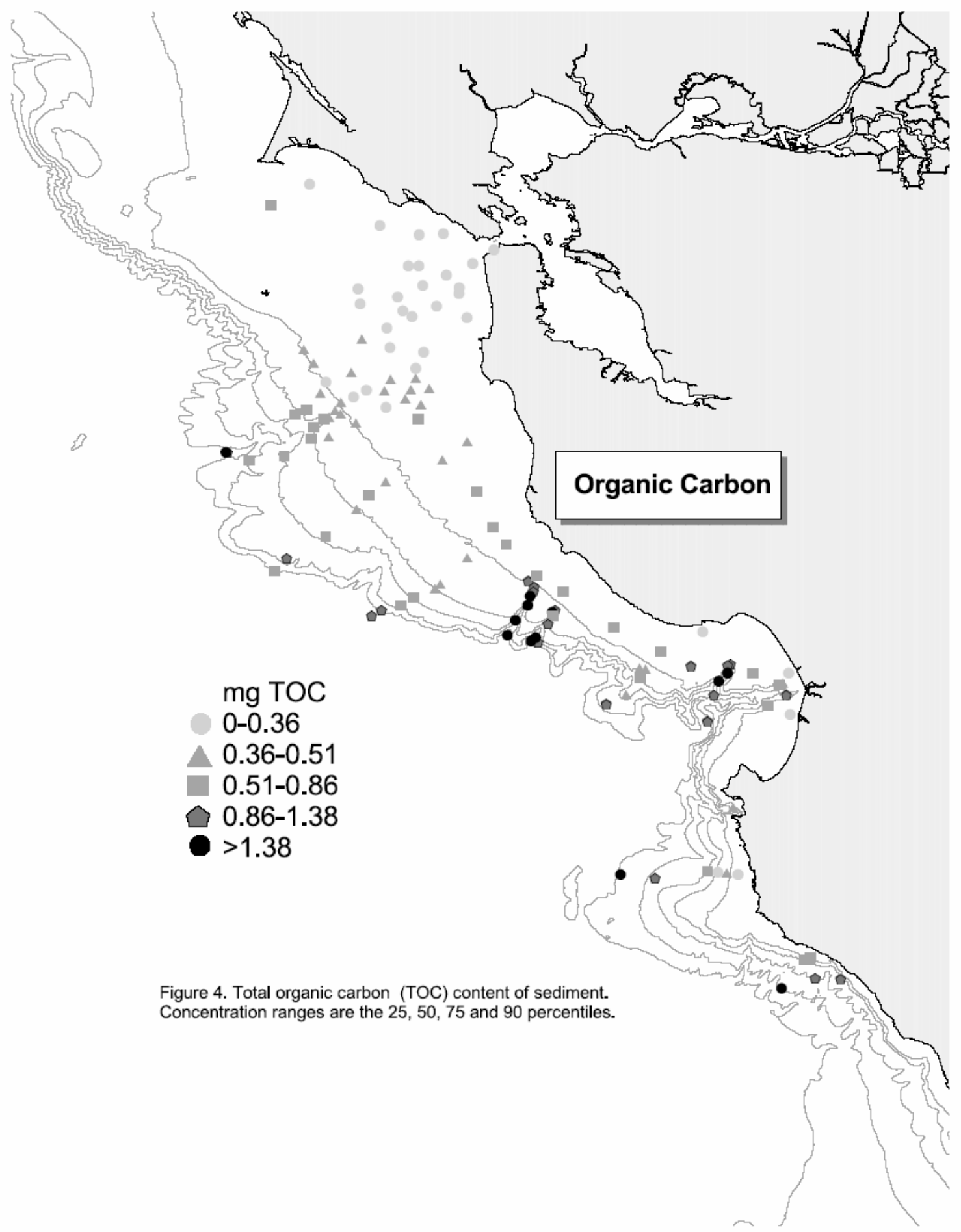




\section{ACCEPTED MANUSCRIPT}

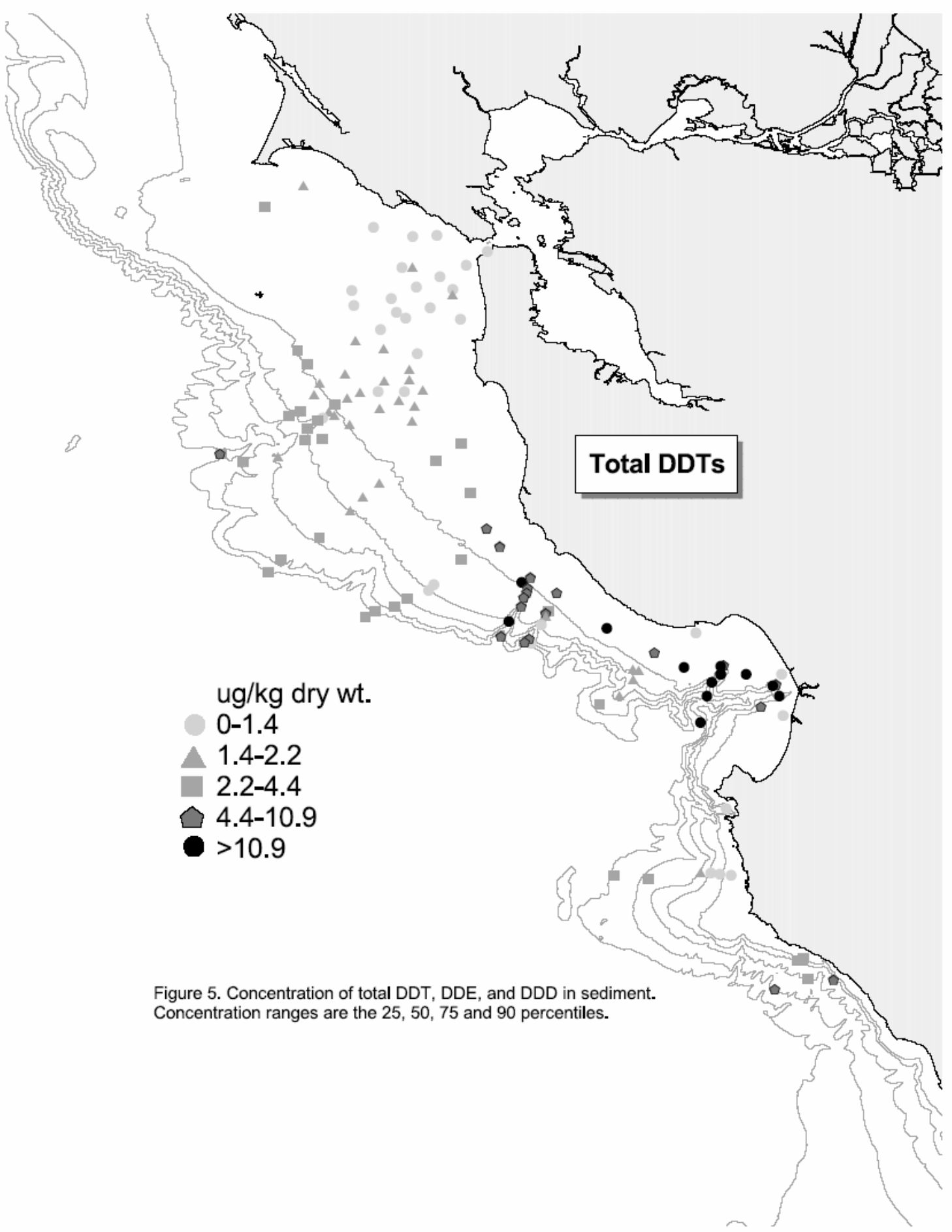




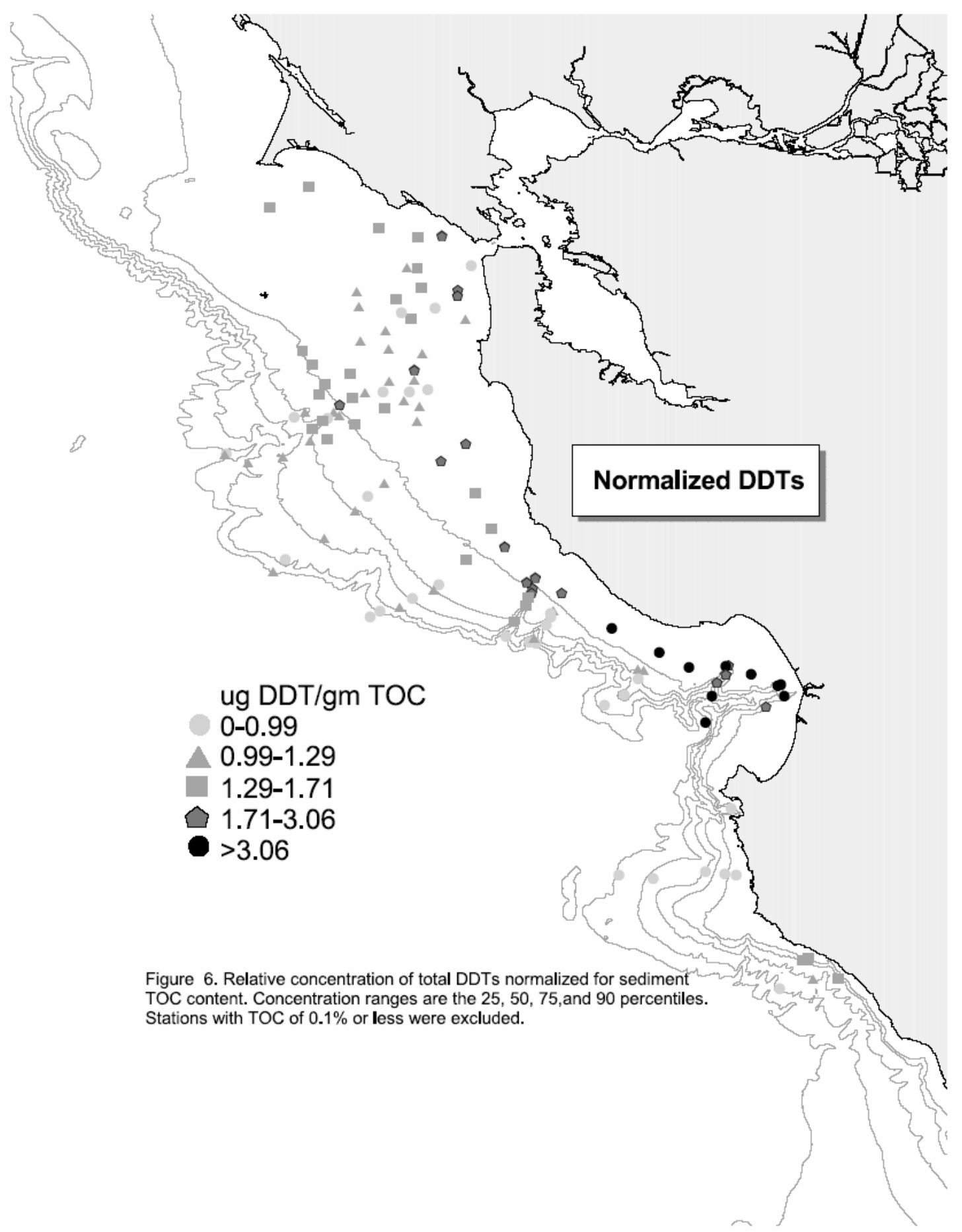




\section{ACCEPTED MANUSCRIPT}

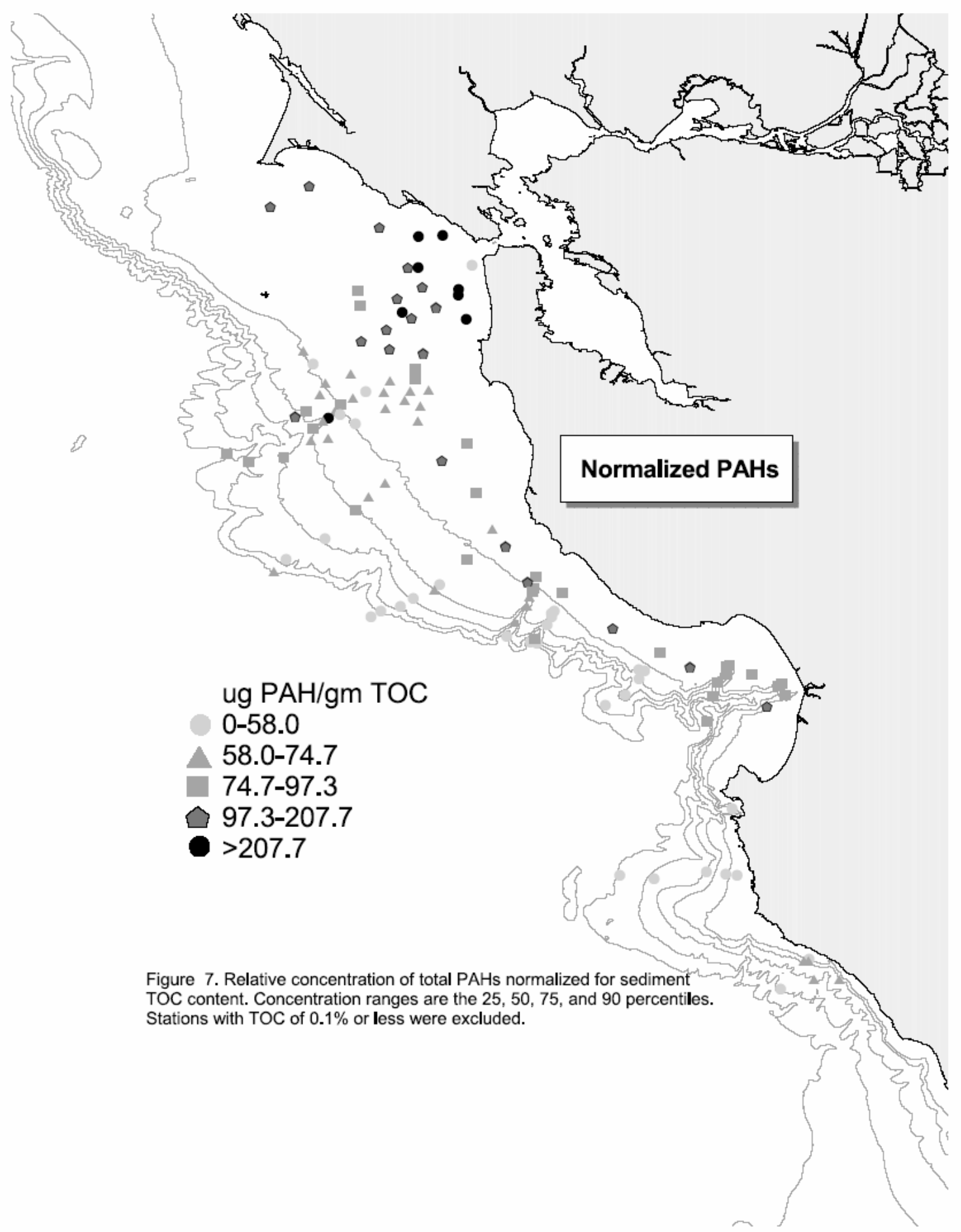




\section{ACCEPTED MANUSCRIPT}

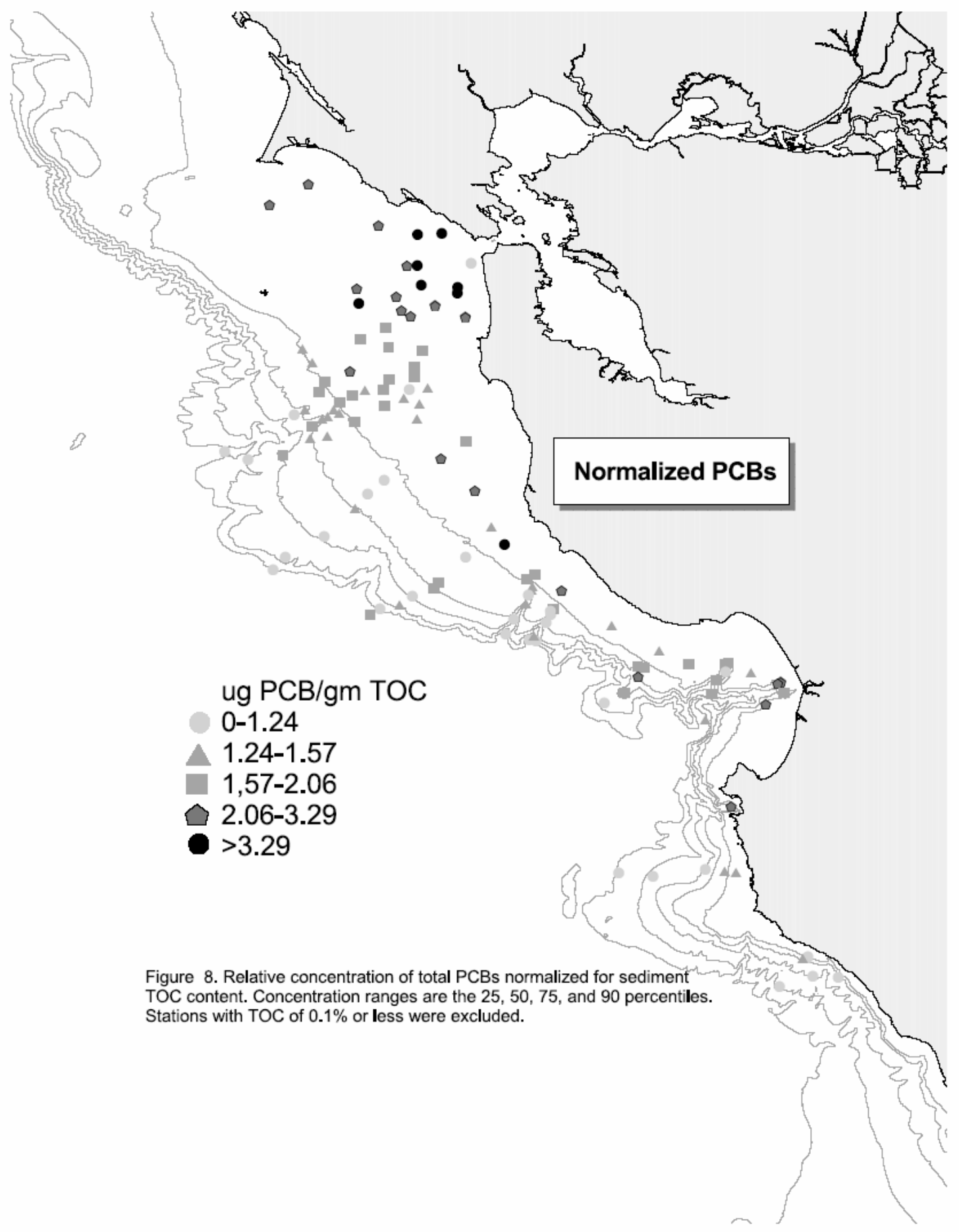




\section{ACCEPTED MANUSCRIPT}

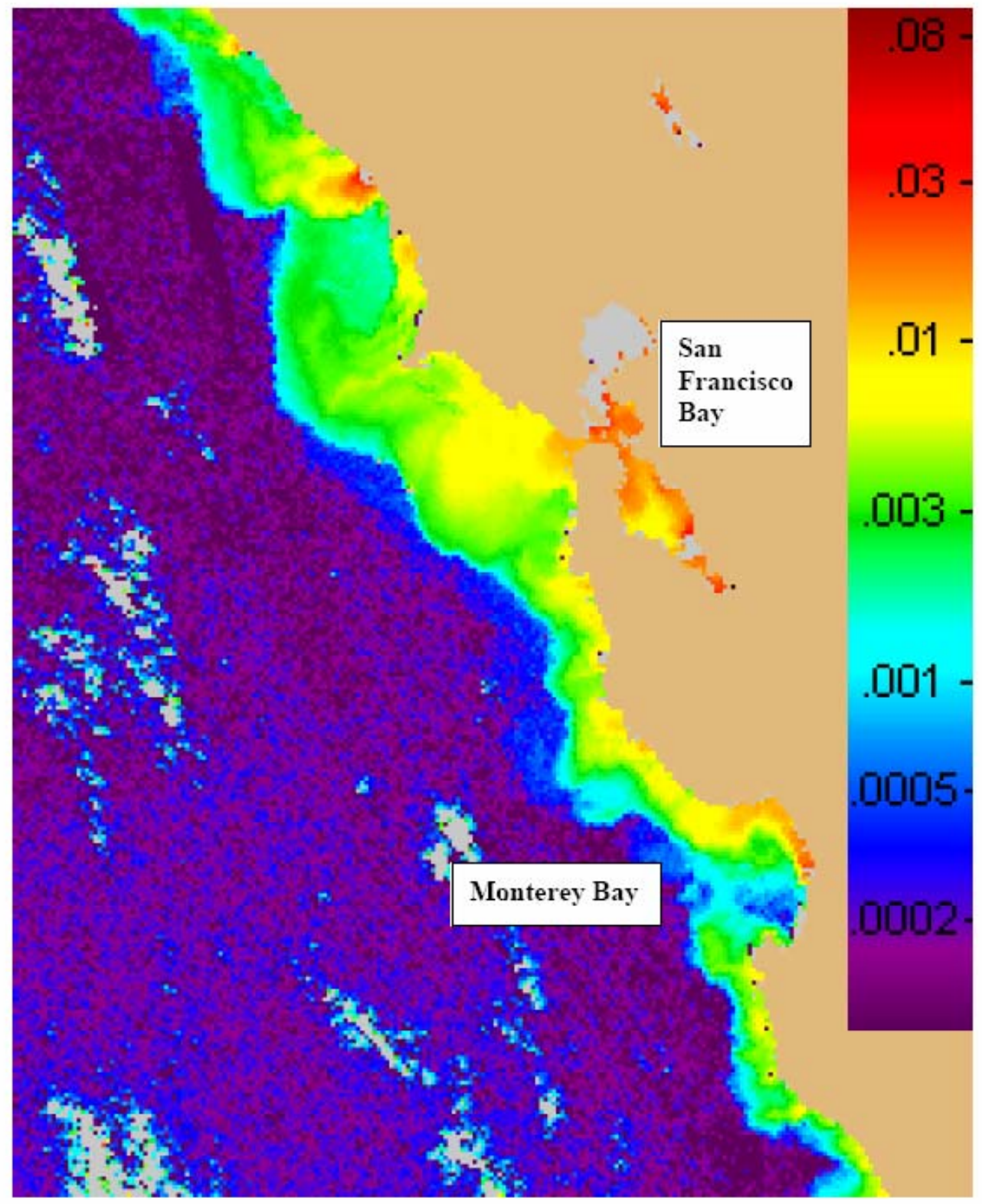

Figure 9. SeaWiFS turbidity spectral analysis image for February 9, 1998. Color scale is in units of Steradian ${ }^{-1}$ at $670 \mathrm{~nm}$. Higher values represent higher sea surface reflectance (=higher turbidity). 